\title{
Biotypology of stream macroinvertebrates from North African and semi arid catchment: Oued Za (Morocco)
}

\author{
Youness Mabrouki ${ }^{1, *}$, Abdelkhaleq Fouzi Taybi ${ }^{1}$, Majida El Alami ${ }^{2}$ and Ali Berrahou ${ }^{1}$ \\ ${ }^{1}$ Université Mohamed Premier, Faculté des Sciences, Département de Biologie, Laboratoire Sciences de l'eau, l'environnement et du \\ Développement Durable, B.P. 524, 60000 Oujda, Maroc \\ ${ }^{2}$ Université Abdelmalek Essaâdi, Faculté des Sciences de Tétouan, Laboratoire Diversité et Conservation des systèmes biologiques \\ (LDICOSYB), B.P. 2121, 93000 Tétouan, Maroc
}

\begin{abstract}
The aim of this study is to investigate the longitudinal zonation of macroinvertebrates assemblages in the Za River basin, the main tributary of Moulouya River (Morocco). This work carried out in three campaigns between March and August 2014 on 12 stations selected. This study allowed the identification of 137 species classified in 109 genera and 65 families. In addition to the physicochemical parameters measured three times in each station, a description of the aquatic environment was made to characterize each of the stations surveyed; in particular with regard to altitude, slope, Emberger quotient, thermal amplitude, kilometers at the source, current velocity and bioclimatic zones. The treatment of this benthic population as well as the stations environmental descriptors, using Foucart' factorial correspondence analysis (FCA) and partial triadic analysis (PTA) respectively, allowed for the development of a typology of this watercourse, where altitude and current speed seem to play a major role in the distribution of benthic invertebrates. The biocenotic study revealed the presence of three stationary groupings corresponding to four faunal groups.
\end{abstract}

Keywords: Za River / Moulouya / Foucart' factorial correspondence analysis / macroinvertebrates assemblages / longitudinal zonation

Résumé - Biotypologie des macroinvertébrés benthiques d'un bassin versant semi-aride du Nord Afrique: Oued $\mathbf{Z a}$ (Maroc). Le but de cette étude est d'étudier la zonation longitudinale des macroinvertébrés benthiques dans le bassin Oued Za, le principal affluent de Oued Moulouya (Maroc). Ce travail réalisé en trois campagnes entre mars et août 2014 sur 12 stations retenues pour cette étude qui a permis l'identification de 137 espèces classées en 109 genres et 65 familles. En plus des paramètres physicochimiques mesurés en trois reprises dans chaque station, une description du milieu aquatique a été faite pour caractériser chacune des stations prospectées ; notamment en ce qui concerne l'altitude, la pente, le quotient d'Emberger, l'amplitude thermique, kilomètre à la source, la vitesse du courant et les étages bioclimatiques. Le traitement de ce peuplement benthique ainsi que les descripteurs environnementaux des stations, respectivement à l'aide de l'analyse factorielle des correspondances (AFC) de Foucart et l'analyse triadique partielle (ATP), a permis l'élaboration d'une typologie de ce cours d'eau où l'altitude et la vitesse du courant semblent jouer un rôle prépondérant dans la répartition des invertébrés benthiques. L'étude biocénotique a révélé la présence de trois groupements stationnels correspondant à quatre groupements faunistiques.

Mots clés : Oued Za / Moulouya / analyse factorielle des correspondances de Foucart / assemblages de macroinvertébrés / zonation longitudinale

*Corresponding author: younes_mab@hotmail.fr 


\section{Introduction}

Within the biological indicators, macroinvertebrates are one of the most employed groups of organisms (Tachet et al., 2010). Among the advantages of their use as bioindicators we can cite their limited mobility and thus reflect the local characteristics of the sampled area, in addition, they are present in most aquatic ecosystems where they are abundant and relatively easy to find; their relatively well known taxonomy; their long enough life cycles and therefore their characteristics are the result of a relatively recent past, including sporadic episodes difficult to detect with chemical or microbiological analyses; they have different sensitivity to different pollutants, reacting rapidly with gradual responses; more than that, because different groups of animals and trophic levels are included, the probability of one of these organisms reacting in the face of an environmental change is high; and finally, the sampling has minimal impact on the resident biota (Platts et al., 1983; Metcalfe-Smith, 1994; Graça et al., 1995; Oscoz et al., 2011).

Consistent patterns of benthic macroinvertebrate community structure and function occur along the length of a river (Illies and Botosaneanu, 1963; Hawkins and Sedell, 1981; Dudgeon, 1984; Singh and Nautiyal, 1990). These communities can vary spatially, temporally and largely in relation to environmental factors (Robinson and Minshall, 1986; Boulton and Lake, 1992; Leland and Fend, 1998). These abiotic factors that influence community structure differ strongly from system to system and with the spatial scale (Tate and Heiny, 1995; Vinson and Hawkins, 1996; Boyero, 2003).

Environmental conditions that have been associated with community structure include water chemistry, bioclimatic zones, altitude and temperature, substrate, depth, etc. In addition, flow variability has strong ecological implications that shape the structure and function of riverine ecosystems (Lytle and Poff, 2004) and stream width have been reported as a key factor structuring invertebrate communities (Heino et al., 2003; Paavola et al., 2003). The riparian zone is also an important factor for the perfect functioning of the River's ecosystem, because it provides food and shelter for the aquatic biota (Bretschko and Moser, 1993).

The typology concept has existed for a long time, Illies and Botosaneanu (1963) have defined a three-level typological zonation system based on aquatic fauna, from this work the terms rhithron and potamon were frequently used in stream ecology. Since then, classification of stream ecosystems using macroinvertebrate communities and multivariate techniques has known a significant use and progress (e.g. Hawkes, 1975; Ormerod and Edwards, 1987; Céréghino et al., 2001).

The quest for links between instream ecology and hydrology has become one of the fundamental issues in contemporary River science (Vaughan et al., 2009). In this Framework, we have made several studies in Oriental Morocco and the basin of Moulouya River, regarding hydrology and monitoring of aquatic ecosystems based on macroinvertebrates communities (Mabrouki et al., 2016a, 2017a, b, 2018; Taybi et al., 2016a, 2017a, b, 2018a, b; Daoudi et al., 2017). Thereby, the objective of this work is to update the inventory of the benthic settlement of the $\mathrm{Za}$ watershed (main tributary of Moulouya River) on the one hand, and on the other, provide an image of the longitudinal zonation of the benthic invertebrates of this North African watercourse.

\section{Material and methods}

\subsection{Description of the study area and sampling sites}

The Za River basin drainage network is located in the north-eastern region of Morocco, it is the main tributary of the Moulouya with an area of $18000 \mathrm{~km}^{2}$, it has its source in the Eastern Highlands and joined Moulouya at Melga El Ouidane, downstream from the town of Taourirt. It drains the southern and western part of the Horsts chain, made up of dolomites and more or less marly limestones. Its general direction is southeast north-west. It crosses from upstream to downstream the arid Mediterranean bioclimatic stage in the High Plateaus, semi-arid in the Horsts and arid range in the Taourirt region (Bensaad et al., 2017; Mabrouki et al., 2016b; Taybi et al., 2016b). Rainfall rates in the region range from 230 to $280 \mathrm{~mm} /$ year, with an average value of $255 \mathrm{~mm} /$ year. The significant rainfall falls in December and April, while July and August are the driest months. The average temperature is $16.4{ }^{\circ} \mathrm{C}$, with the minimum values of $4{ }^{\circ} \mathrm{C}$ in January and the maximum of $42^{\circ} \mathrm{C}$ in August (Mabrouki et al., 2016a).

\subsection{Macroinvertebrate data}

The benthic invertebrate samples were taken with a "Surber" sampler (with a surface of $20 \times 25 \mathrm{~cm} \times 8$ samples $=$ $0.40 \mathrm{~m}^{2}$ ) equipped with a $500 \mu \mathrm{m}$ mesh net. The quantitative samples (of an order of eight) for the different microhabitats present on the site are made against the current of water. The choice of microhabitats selected is based both on their biogenic capacity (favorable to aquatic life), their representativeness within the station and the different classes of current velocity on the site. The mainly qualitative benthic fauna samples were taken by nets, dip nets and forceps. The capture of the adults was carried out with a sword net and a Japanese umbrella. While Trichoptera pupae were raised in the laboratory for adults.

For each sample, a first sorting was carried out on the field during which the fauna was preserved in a jar containing $70^{\circ}$ alcohol. A second and finer sorting was performed in the laboratory under a binocular loupe in which all remaining macroinvertebrates were recovered and stored in $70^{\circ}$ alcohol.

\subsection{Mesological descriptors}

In addition to the physicochemical parameters measured three times in each station (Fig. 1), a description of the aquatic environment was made to characterize each of the stations surveyed; in particular with regard to altitude, slope, Emberger quotient, thermal amplitude, kilometers at source, current velocity and bioclimatic zones (see Tab. S1).

Longitude, latitude and altitude were taken directly on the field using an "Altimeter PRO" GPS. The bioclimatic floors of Emberger developed by us from the map 


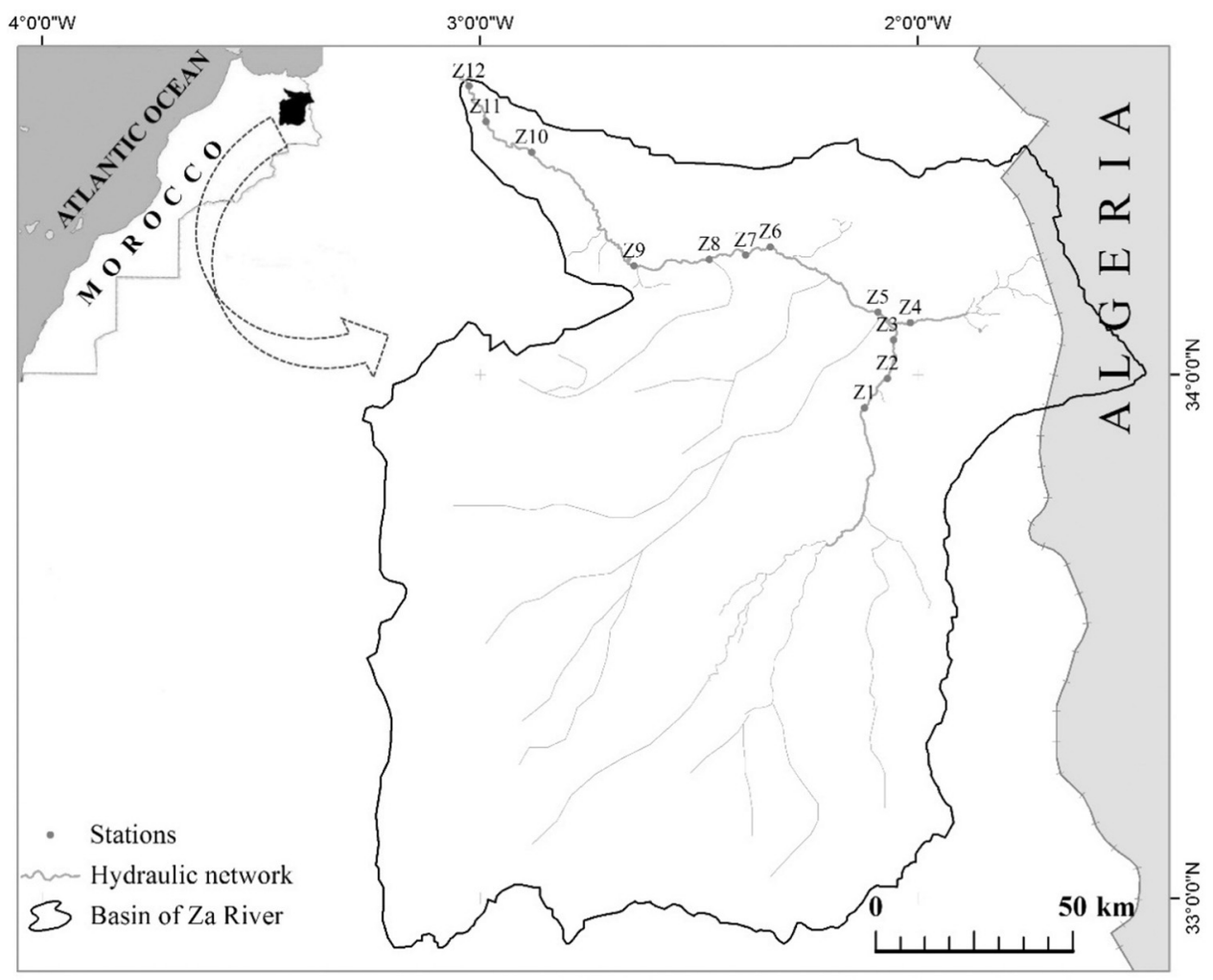

Fig. 1. Situation of the $\mathrm{Za}$ watershed and the stations selected for this study.

established at the scientific institute of Rabat (former Scientific Chérifien Institute) by Brignon and Sauvage (1962). The Emberger quotient, the thermal amplitude (M$\mathrm{m})$, and the slope were calculated from 1/50000 maps. Kilometers at the source; this distance was measured directly by ARCGIS software, version 10.2 "geographic information systems".

The parameters of the average slope, the thermal amplitude and the bioclimatic stages were transformed into modalities:

- the average slope (in \%o): $1=\mathrm{PM}<110 ; 2=110<\mathrm{PM}$ $<220 ; 3=\mathrm{PM}>220$;

- thermal amplitude M-m: $1=\mathrm{M}-\mathrm{m}<25^{\circ} \mathrm{C} ; 2=25<\mathrm{M}$ $\mathrm{m}<35^{\circ} \mathrm{C} ; 3=\mathrm{M}-\mathrm{m}>35^{\circ} \mathrm{C}$;

- bioclimatic floors: 1: Saharian with cold winter; 2: arid with cold winter; 3 : arid with temperate winter; 4 : semiarid with cold winter; 5 : semi-arid with temperate winter; 6: semi-arid with warm winter; 7: sub-humid with cold winter; 8: humid with cold winter;

- current velocity: this component of the field, well known for its selective action on stands, was quantified by its average value at three different locations of the same station. In the absence of a hydrometric reel to measure the velocity of the current, we have estimated it by means of a stopwatch at various points of the stream, by measuring the time taken by a floating body to traverse a given distance. The average speed (converted to $\mathrm{cm} / \mathrm{s}$ ) was the subject of a semi-quantitative estimation, followed by a transformation into four modalities: $1=$ very low current at inexistent $<5 \mathrm{~cm} / \mathrm{s} ; 2=$ weak current $5<2<25 \mathrm{~cm} / \mathrm{s} ; 3=$ average current $<3<50 \mathrm{~cm} / \mathrm{s}$; $4=$ fast current $>50 \mathrm{~cm} / \mathrm{s}$.

\subsection{Approach method}

To study the longitudinal zonation, we have selected the pristine or least disturbed stations, those that showed signs of stress and strong anthropogenic action will be eliminated later.

Our data describe the benthic settlement and abiotic components of stations in the $\mathrm{Za}$ watershed (Fig. 1). These stations were sampled bimonthly three times between March and August 2014. Each campaign provided two tables, one for wildlife and stations (fauna-stations) and the other for abiotic factors and stations (biotope-stations).

The data studied are therefore composed of six tables (two per campaign) covering the same 12 stations (see Mabrouki et al., 2016b for more details) and the same faunistic and abiotic descriptors (Tabs. S1 and S2). The objective of this work is to look for a species-station spatial typology common to the different prospecting dates and to study its stability. The analysis of such tables then raises problems that conventional multivariate analysis methods (FCA, PCA, MCA) do not allow to address it satisfactorily. Statistical analyzes adapted to this problem are called multitables analyzes.

For our multidimensional data, we opt for the partial triadic analysis (PTA) which works with a PCA logic and the FCA of Foucart. Recall that the purpose of these two methods is to find a spatial structure (typology) common to all campaigns and to study the temporal stability around this average structure. For 


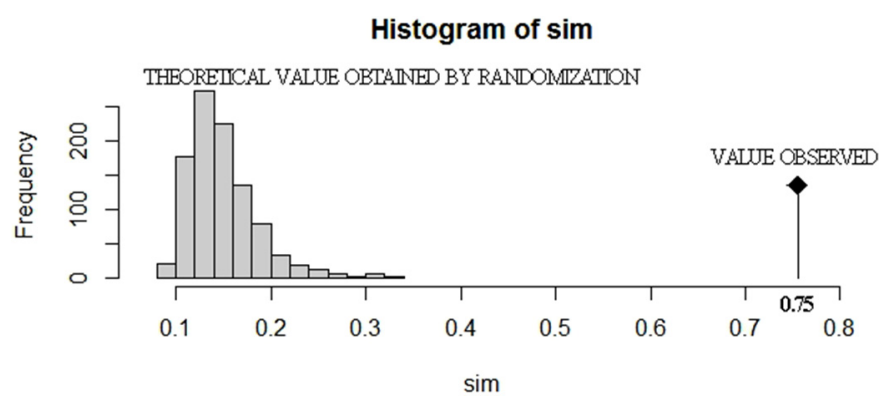

Fig. 2. Permutation test on the co-inertia of the two wildlife and environment tables of Za River.

this, it relies first on the search for an average of tables called "compromise" that we analyze, then on the reproducibility of the compromise by each of the initial tables. In our case of uses, we focus on the compromise.

Foucart' FCA, based on a logic of FCA, allows approaching three-dimensional data type: species-stationscampaigns. Although the application examples in ecology are relatively rare, its use demonstrates the effectiveness of this method as a judicious way of organizing stations according to the similarities between their stands and to appreciate how their species react to environmental factors (Baran, 1995; Gaertner, 1997; Blanc and Beaudou, 1998; Blanc, 2000; Taybi, 2016).

In order to homogenize the variances and minimize the non-normality effects, all our data were undergo a "log transformation": $y=\log (x+1)$. We started with an overall analysis of the data set consisting of 36 surveys (12 stations $\times 3$ campaigns)/99 species (see Tabs. S1 and S2).

The abiotic descriptors taken into account in the description of the aquatic environment are likely to play a role in the distribution of the benthic fauna. A search of a global mesological structure of the environment from these abiotic descriptors will serve as a support for a comparative study of fauna distribution.

In order to make a typology of the rivers prospected according to their affinities and to identify the parameters or components of the environment responsible for the benthic fauna spatial distribution, a typological study was carried out through a matrix of 13 ecological parameters considered by hydrobiologists (Dakki, 1987; El Agbani et al., 1992; El Alami, 2002) as ecological factors capable of governing life in aquatic environments (Tab. S2).

This working methodology is accepted only if we can highlight a link or a relationship between the environment and the fauna. To answer the question of a possible relationship between environmental factors and the population of benthic invertebrates during the three campaigns; we used a co-inertia analysis.

The co-inertia analysis (Dolédec and Chessel, 1987) is the only one to tolerate any size on both sides, and is practically the only one that can be used if the environmental variables are qualitative. This is the simplest analysis, since; it does a double analysis of inertia tables and ensures that the two coordinate systems are as consistent as possible.
The study of the fauna-environment relationship thus involves the coupling of the global faunal table (stations $\times 3$ campaigns $=$ surveys $\times$ species) with the table of environmental variables (surveys $\times 13$ variables). The global faunistic table of the $\mathrm{Za}$ watershed after elimination of the polluted station gives us a dataset composed of 33 surveys $\times 96$ species (11 stations $\times 3$ campaigns $=33$ surveys $\times 96$ species ).

The study of fauna-environment relationship involves thus the coupling of the global faunal table (11 stations $\times 3$ campaigns $=33$ surveys $\times 96$ species) with the table of environmental variables ( 33 surveys $\times 13$ variables).

The relevance of the co-inertia analysis is verified by a Monte-Carlo permutation test (Manly, 1991) on 1000 random permutations (Fig. 2). The value observed $(r=0.75)$ corresponds to the correlation coefficient between the coordinates of the faunistic data and the coordinates of the environment on the co-inertia axes. This value (with a $p$ value $=0.001)$ is higher than the values obtained by random draws (randomization) which indicates that the two structures (environment and benthic settlements) are significantly linked: there is indeed a co-structure. A search for a global mesological structure of the environment from these abiotic descriptors is therefore justified.

\section{Results}

This study allowed the identification of 137 species listed in 109 genera and 65 families.

To avoid a biased structural analysis, rare and/or accidental species were eliminated with very low occurrences (minimum frequency in all stations and per campaign $=3$ ), and only specimens identified to the species rank were kept. Of the 137 specimens identified, only 99 were retained for further analysis (see table in Tab. S1).

After a first FCA of Foucart, the Z11 station was well insulated on the left of the F1 axis, it is a polluted station that is influenced by urban and industrial wastewater from the city of Taourirt (Mabrouki et al., 2016b). Our main goal is to establish a biotypology of Za River. Thus, the polluted station Z11 was no longer considered in the rest of the study; consequently, three species were eliminated from $\mathrm{Za}$ 's dataset, the latter is consisted of only 96 specimens.

\subsection{Search for a mesological structure}

The compromise of the partial triadic analysis of $\mathrm{Za}$ River (Fig. 3) cumulates $79.17 \%$ of the total information on the F1-F2 plan; and shows that there is a stable average structure between the three campaigns. The F1 axis, which totals $61.95 \%$ of the total information, expresses an upstream-downstream gradient. It separates high altitude stations with low conductivity ( $Z 1$ and $Z 2$ ) from low altitude ones with high conductivity (Z9, Z10 and Z12). The F2 axis, which represents $17.22 \%$ of the total information, expresses the speed of the current by separating the stations where the velocity of the current is strong $(\mathrm{Z} 3, \mathrm{Z} 4, \mathrm{Z} 5, \mathrm{Z6}, \mathrm{Z7}$, and $\mathrm{Z} 8)$ down the axis. The station $Z 12$ located in the middle of the axis F2 expresses a global average speed (Fig. 4). 


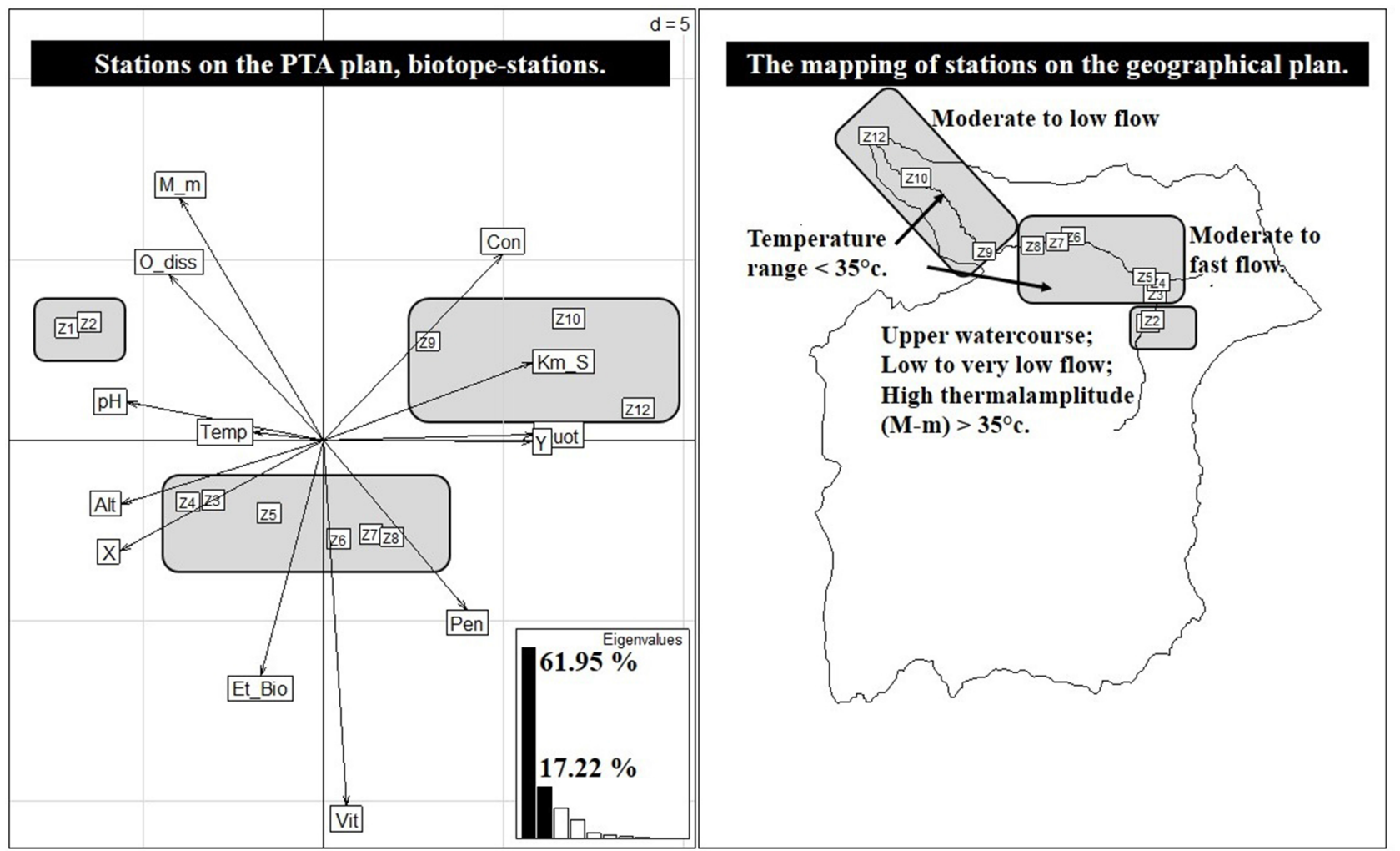

Fig. 3. Typological synthesis test of Za River basin using the explanatory mesological variables of the TPA first two factorial axes (with Alt: altitude; Pen: the average slope; Vit: current velocity; Et_bio: bioclimatic floors; Y: latitude; X: longitude; O_diss: dissolved oxygen; Con: conductivity; pH: hydrogen potential; Temp: temperature; Km_S: kilometers at the source; M-m: thermal amplitude; Quot: the Emberger quotient).

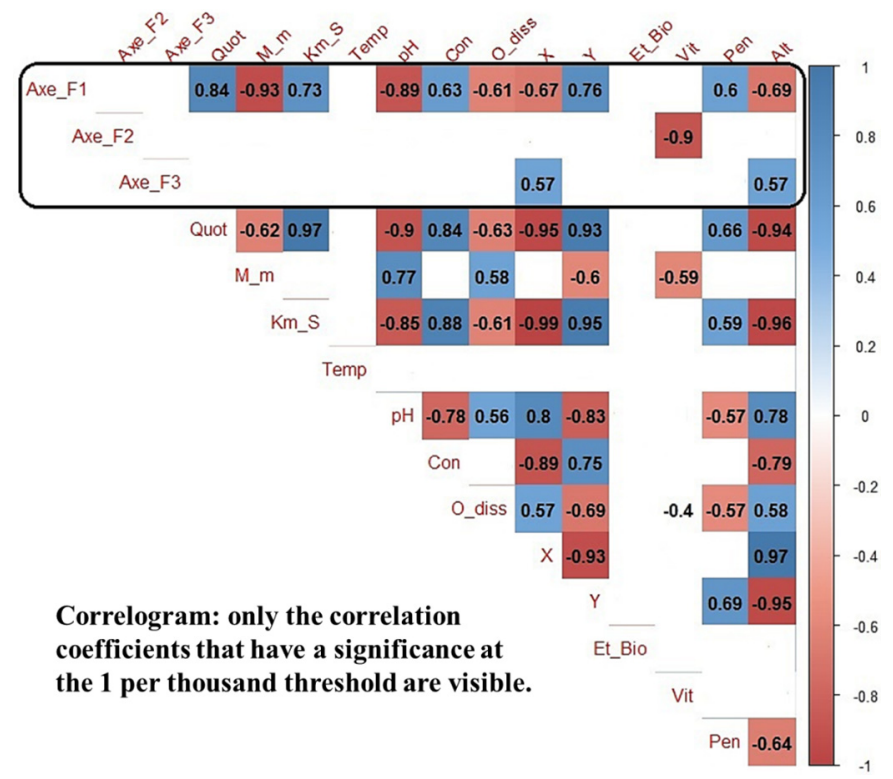

Fig. 4. Correlogram: Pearson correlation between the different parameters measured and the first 3 axes of Foucart' FCA.

\subsection{Biotypological structure}

Figure 5 (left) shows the stations distribution on the F1-F2 factorial plane of the Foucart' FCA (by data set consisting of 11 stations $\times 3$ campaigns $\times 96$ species). This analysis shows in the F1-F2 plane a clouds organization of the stations and the species (points) into a V-shaped structure, denoting the existence of a pronounced gradient expressed along the F1 axis. The junction of the stations according to their order of succession in nature makes it possible to link, at first glance, the aforementioned gradient to an "upstream-downstream" succession.

To clarify, the possible relationship between the biotypological structure and the variables of the environment, we confronted the two compromises of the first two F1-F2 plans of Foucart' FCA (stations/species) and TPA (stations/environment). Figure 5 shows the stations seen by the species and the same stations seen by the environment.

The structure of the stations defined by the mesological analysis (stations are seen by the environment) is very close to that defined by the fauna (stations seen by the species). Only the Z12 station, which is moving away in the TPA from the group defined by fauna in Foucart' FCA, 


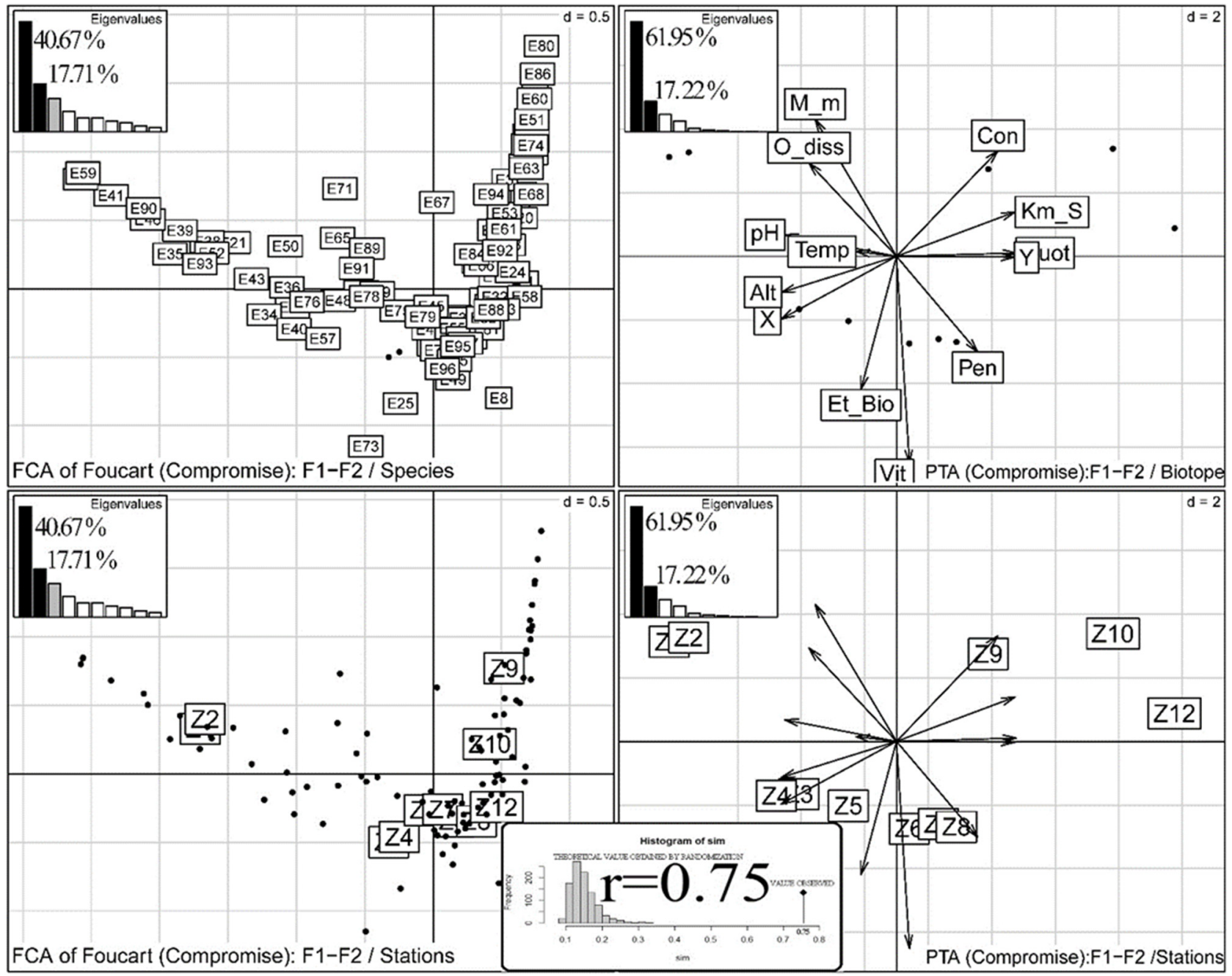

Fig. 5. Projections of the stations on the F1-F2 plan of the Foucart' FCA compromise and the TPA. Left: The stations viewed by species. On the right the stations seen by the environment; $r(=0.75)$ corresponds to the correlation coefficient between the coordinates of the faunistic data and the coordinates of the environment on the co-inertia axes.

probably because of the disturbance caused by the heavy pollution experienced upstream of this station $(\mathrm{Z} 11)$.

\section{Axes signification}

To understand the possible relationship between the typological structure and the variables of the environment, we compared the coordinates of the stations (seen by the fauna) on the first three factorial axes (FCA of Foucart) to the values of the mesological parameters (Tab. S1) that can intervene in the distribution of the fauna (Fig. 6).

\subsection{Signification of F1 axis ( $40.67 \%$ of total inertia)}

The Pearson correlation coefficients have been put to a test of significance (Fig. 4), only the coefficients that have a significance at the threshold of 1 per thousand were retained in the analysis.
Nine environmental parameters have a good correlation with the FI axis (Fig. 7). In descending order of correlation, we find $\mathrm{pH}(r=-0.89)$, Emberger's quotient $(r=0.87)$, altitude $(r=-0.85)$, kilometer at source $(r=0.73)$, latitude $(r=0.76)$, longitude $(r=-0.67)$, conductivity $(r=0.63)$, dissolved oxygen $(r=-0.61)$, and slope $(r=0.60)$. The mesological structure obtained in the F1-F2 plan makes it possible to emerge on the F1 axis a gradient whose meaning is of great value for ecologists: it is the upstream-downstream gradient of watercourses. In this cloud of stations, we have therefore a very sharp upstream-downstream gradient (Fig. 5).

\subsection{Signification of F2 axis (17.71\% of total inertia)}

A single mesological parameter has a fairly good negative correlation with the second factorial axis, it is the speed of the flow $(r=-0.62)$. The F2 axis thus expresses a current velocity gradient. The stations at the top of the F2 axis globally record a low average speed of their respective currents (Z1, Z2, Z9, Z10 

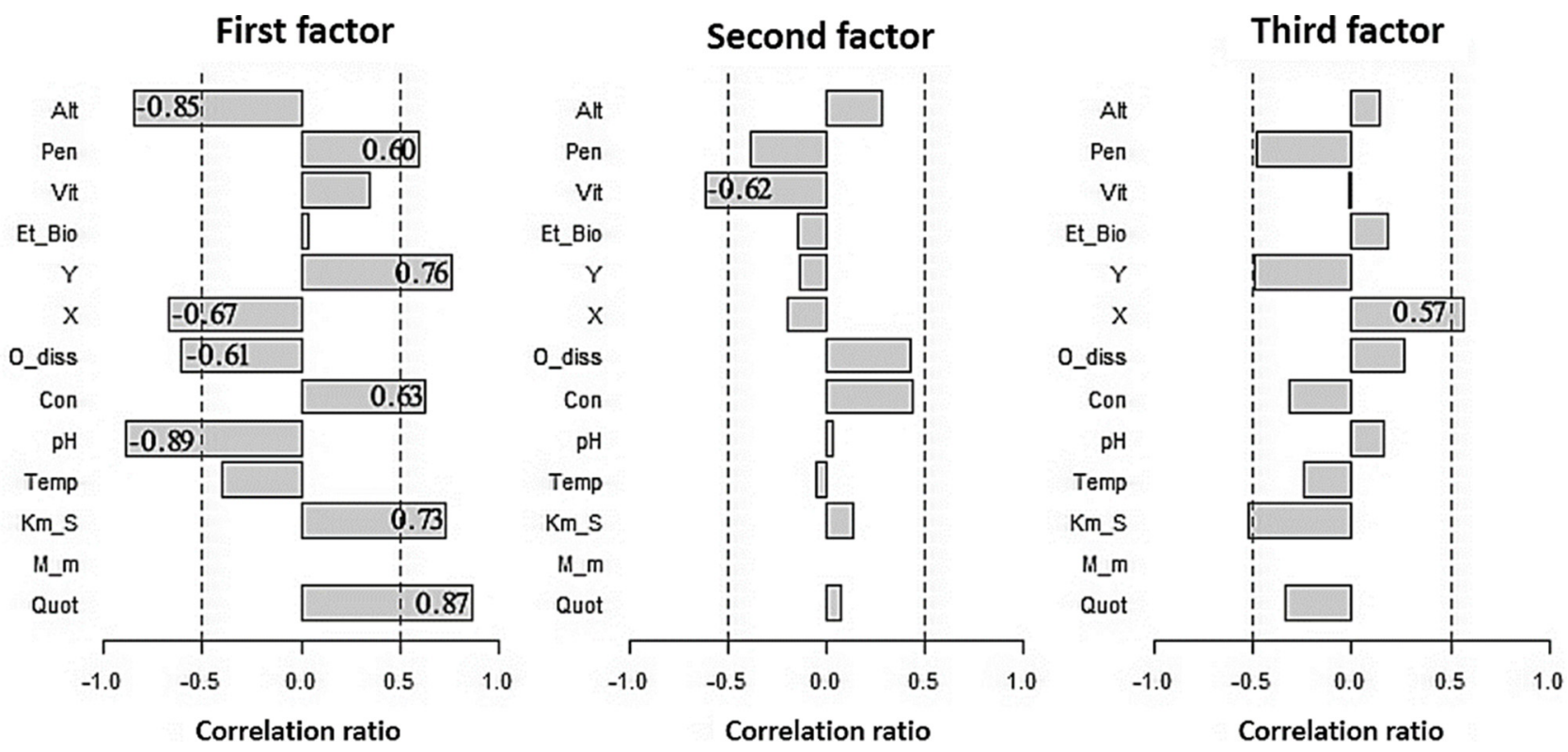

Fig. 6. Correlation ratio between mesological parameters and the first three axes of Foucart' FCA (with Alt: altitude; Pen: the average slope; Vit: current velocity; Et_bio: bioclimatic floors; Y: latitude; X: longitude; O_diss: dissolved oxygen; Con: conductivity; $\mathrm{pH}$ : hydrogen potential; Temp: temperature; Km_S: kilometers at the source; M-m: thermal amplitude; Quot: the Emberger quotient).

and $\mathrm{Z} 12)$. The flow of water in stations down the axis $(\mathrm{Z} 3, \mathrm{Z} 4$, $\mathrm{Z5}, \mathrm{Z6}, \mathrm{Z7}$ and $\mathrm{Z8}$ ) is generally moderate.

\subsection{Signification of the $\mathrm{F} 3$ axis $(12.28 \%$ of total inertia)}

A single parameter has a positive correlation with the third factorial axis, it is the longitude $(r=0.57)$. This factor is already highlighted on the F1 axis; the mesological parameters used in this study do not tell us more about the distribution of stations and species on the F3 axis. This axis (F3) may express another factor not measured in this study, such as substrate nature or riverbed width.

The mesological structure obtained in the F1-F2 plan brings out two main gradients whose meaning is of great value for ecologists: the first factorial axis reproduces an upstream-downstream gradient of streams (with all that involves from a point of view of altitude, temperatures, etc.) and the second tends to separate the stations according to the speed of the stream.

\section{Discussion}

The concordance of the mesological and biological structures has already been found in other moroccan rivers, as in Sebou (Dakki, 1987), Bou Regreg (El Agbani et al., 1992) and the Moulouya (Berrahou et al., 2001; Taybi, 2016).

In front of such a mesological parameters number explaining, among others, only $58.38 \%$ of the total inertia of the biological structure. We agree with the opinion of Ulfstrand (1967), Bournaud and Keck (1980) and Dakki (1987) who argue that the determinism of biocenosis cannot be explained solely by simple relationships between a parameter mesological and such species; and that it is impossible to specify with any precision and rigor the level of action of each component along the biological structure, it is rather the combined result of the various ecological factors that manage this structure.

To establish a biotypology of the benthic stands of $\mathrm{Za}$ watershed, only the insect stands, namely Plecoptera, Trichoptera, Ephemeroptera, and Coleoptera Elmidae been used. These groups (good zonators) are relatively well known in Europe and North Africa to allow easy comparisons, both bio-typologically and in terms of their autecology (El Agbani, 1984; Dakki, 1987; Bouzidi, 1989).

The increase of a species density in a given biotope generally reflects an optimization of the favorable factors for its development. The order of the species on F1 factors of the Foucart' FCA compromise (Fig. 7) brings together the species with similar stationary distribution. This order, as well as the density of a given taxon were adopted for the presentation of the species. Of cuts in these sequences are used to define four faunal groups over three station groups (Fig. 3):

- grouping A: it is composed of Allotrichia pallicornis (E35), Cloeon dipterum (E21), Agraylea sp. (E34), and Orthotrichia angustella (E36). It is a stand of hot rivers of medium and high altitude $(\mathrm{Z} 1<950 \mathrm{~m})$ with low flow. Species in this group have generally higher abundance in predominantly slow-flow stations as is the case in $\mathrm{Z} 1$ and $\mathrm{Z} 2$ stations. Their presence in the middle courses of $\mathrm{Za}$ River makes them eurythermic limnophilic species of moderate and high altitude preferring warm biotopes;

- grouping B: this group is widespread in the watershed of Za. Generally, regularly high abundances are observed all along the rivers, which explains its low degree of 


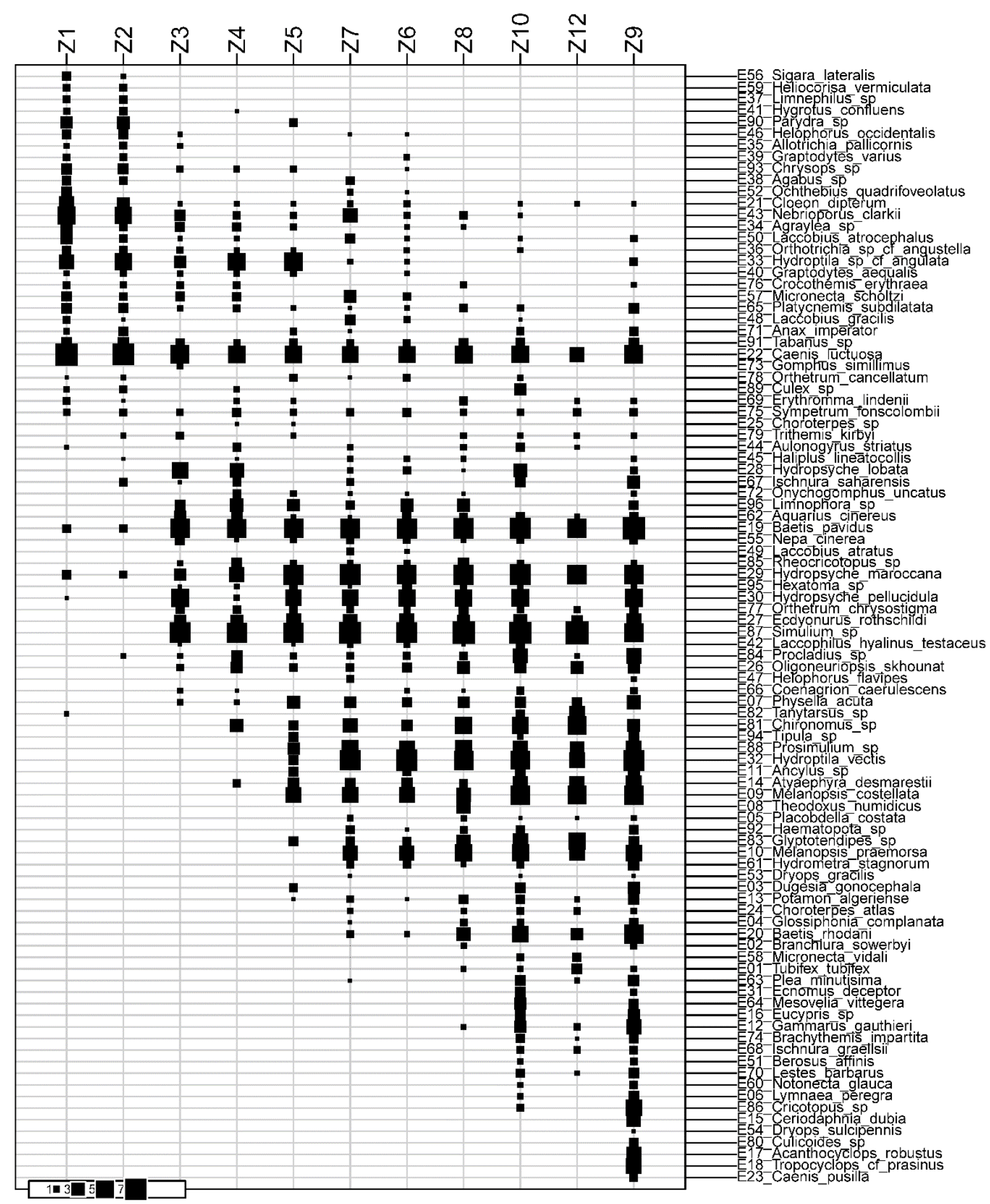

Fig. 7. Species and stations ordination along F1 axis of Foucart' FCA compromise. The black squares represent the total abundance transformed into $\log (x+1)$.

preference. These are the eurytope species, the most ubiquitous in Za River: Caenis luctuosa (E22), Baetis pavidus (E19) and Hydroptila sp cf angulata (E33);

- grouping C: Hydropsyche pellucidula (E30), Hydroptila vectis (E32), Ecdyonurus rothschildi (E27), Hydropsyche lobata (E28), Hydropsyche maroccana (E29) and Oligo- neuriopsis skhounate (E26), prefer fast-flowing waters, they are both thermophilic rheophilic taxa indicating that stations Z3 to Z8 have a moderate to rapid dominant flow; - grouping D: the fourth group settles downstream of the Za River dam. The latter directly influences the distribution of the benthic fauna thanks to the strong stability of the 
biotopes it generates downstream (well-developed riparian forest). The Z9 station located just after the dam has the highest specific richness of the $\mathrm{Za}$ watershed. The main channel stream of the Z9 has a stable moderate flow that can become rapid in winter, the rest of the stream in the banks of the bed has a predominant slow flow. The contrast of this flow can bring together species a with different affinity for the flow as Caenis pusilla (E23) and Baetis rhodani (E20) who prefer fast-flowing rivers, and Choroterpes atlas (E24), which prefers moderately to moderately flowing rivers.

The species of this group are all thermophilic eurytherms preferring temperate waters of medium and low altitudes. In the high atlas Caenis pusilla seems to be more alticole (500 2600 m, Bouzidi, 1989).

The anthropogenic pollution experienced by the Z11 station (eliminated in the biotypical study) explains partly the disturbance of the Z12 station. The latter, which is returning to normalcy, is closer to Group 2 (stations Z3 to Z8) than to Group 3 which is composed of Z9 and Z10.

The longitudinal distribution of benthic invertebrates in $\mathrm{Za}$ watershed is governed, among others, by two major environmental factors: altitude and flow velocity. The fauna/ altitude relation is well indicated on the upstream-downstream gradient, in fact, this gradient, which is correlated with the distance to the source, conductivity, and $\mathrm{pH}$, subdivides the benthic fauna of $\mathrm{Za}$ River into four groups which are all thermophilic eurytherms, preferring the warm waters of medium and low streams. This diagram of upstreamdownstream typology is already highlighted in Morocco by several studies, conducted on different big rivers: Sebou (Dakki, 1987), Bou Regreg (El Agbani et al., 1992), Oum Rbia (Bouzidi, 1989), Tensift (Bouzidi, 1989) and the Moulouya (Berrahou et al., 2001; Taybi 2016).

As a conclusion, most of the species found in the $\mathrm{Za}$ watershed are thermophilic; their distribution is governed by their affinities for the watercourse velocity. The dam built on this watercourse gives on its downstream temporal stability for biotopes. The four faunistic groups of $\mathrm{Za}$ are respectively:

- a group with generally higher abundance in predominantly slow-flowing stations. Their presence in the middle-stream of $\mathrm{Za}$ makes them eurythermic limnophilic species of average and high altitudes preferring warm biotopes;

- a widespread group in the Za catchment. Generally, regularly high abundances are observed all along the watercourse, which explains its low degree of preference. These are the Eurytopic species, the most ubiquitous in $\mathrm{Za}$ catchment area;

- a group preferring moderately to rapidly flowing waters, they are both thermophilic rheophilic taxa;

- the fourth group settles downstream of the Oued Za dam. The latter directly influences the distribution of the benthic fauna thanks to the strong stability of the biotope that it generates downstream (well-developed riparian forest...etc). The water velocity contrast in this section can group species with different flow affinity, such as Caenis pusilla and Baetis rhodani, which prefer fast-flowing rivers, and Choroterpes atlas that prefers rivers with moderate velocity to no flow.
With reference to the longitudinal ecological zonation scheme of running waters considered mainly from the faunistic point of view (Illies and Botosaneanu, 1963); the Za River includes species that most researchers describe as characteristics of the potamal (El Agbani, 1984; Dakki, 1987; Gagneur and Thomas, 1988; Bouzidi, 1989; El Alami, 1989). It corresponds to the population of thermophilic stands in low and mid-altitude hot rivers that Dakki (1987) proposed when comparing the biocenotic structures of high Sebou with those of other Moroccan rivers. Our biocenotype includes a very large number of potamic species; some are rheophilous $(E$. rothschildi) the others have a clear preference for moderate to zero currents (Choroterpes atlas and Cloeon dipterum). In conclusion, the main stream of $\mathrm{Za}$ is comparable to a large potamon.

\section{Supplementary Material}

Table S1. Matrix of faunistic data

Table S2. Matrix of mesological data of the studied stations.

The Supplementary Material is available at https://www.kmaejournal.org/10.1051/kmae/2019009/olm.

Acknowledgment. We would like to thank the reviewers for their constructive criticism and helpful comments.

\section{References}

Baran E. 1995. Dynamique spatio-temporelle des peuplements de poissons estuariens en Guinée, Afrique de l'Ouest. Ph.D. thesis, Université de Bretagne Occidentale, Brest, France, 236 p.

Bensaad H, Mabrouki Y, Taybi AF, Chafi A. 2017. Assessment of wastewater discharges from Taourirt City on the water quality of the Oued Za (Eastern Morocco). J Mater Environ Sci 8(7): 2365-2371.

Berrahou A, Cellot B, Richoux P. 2001. Distribution longitudinale des macroinvertébrés benthiques de la Moulouya et de ses principaux affluents (Maroc). Ann Limnol 37(3): 223-235.

Blanc L. 2000. Données spatio-temporelles en écologie et analyses multitableaux: examen d'une relation. Ph.D. thesis, Université Claude Bernard-Lyon I, Lyon, France, $266 \mathrm{p}$.

Blanc L, Beaudou D. 1998. Stabilité temporelle des structures spatiales des peuplements piscicoles des régions LanguedocRoussillon et Provence-Alpes-Côte d'Azur. B Fr Peche Piscic 348: 23-45.

Bournaud M, Keck G. 1980. Diversité spécifique et structure des peuplements de macro-invertébrés benthiques au long d'un cours d'eau: le Furans (Ain). Acta Oecol-Oecol Gen 1(2): 131-150.

Bouzidi A. 1989. Recherches hydrobiologiques sur les cours d'eau des massifs du Haut Atlas (Maroc). Bio-écologie des macroinvertébrés et distribution spatiale des peuplements. Ph.D. thesis, Université Cadi Ayyad, Marrakech, Morocco, $190 \mathrm{p}$.

Boulton A, Lake PS. 1992. The ecology of two intermittent streams in Victoria, Australia. III. Temporal changes in faunal composition. Freshw Biol 27(1): 123-138

Boyero L. 2003. Multiscale patterns of spatial variation in stream macroinvertebrate communities. Ecol Res 18: 365-379 
Bretschko G, Moser H. 1993. Transport and retention of matter in riparian ecotones. Hydrobiologia 251: 95-101.

Brignon C, Sauvage CH. 1962. Étages bioclimatiques. Bull Inst Sci Rabat, $\mathrm{N}^{\mathrm{o}} 6 \mathrm{~b}$, Bulletin de l'Institut scientifique de Rabat (ex Institut Scientifique Chérifien), Atlas du Maroc.

Céréghino R, Giraudel JL, Compin A. 2001. Spatial analysis of stream invertebrates distribution in the Adour-Garonne drainage basin (France), using Kohonen self organizing maps. Ecol Modell 146: $167-180$.

Dakki M. 1987. Ecosystèmes d'eau courante du Haut Sebou (Moyen atlas): étude typologiques et analyses écologique et biogéographique des principaux peuplements entomologiques. Bull Inst Sci Rabat 42: 1-99.

Daoudi L, Chavanon G, Taybi AF, Mabrouki Y. 2017. Contribution to the knowledge of riparian Coleoptera of Ait Aissa wadi region of Beni Tadjite-Talsint (Eastern Morocco). J Mater Environ Sci 8(8): 2903-2915.

Dolédec S, Chessel D. 1987. Rythmes saisonniers et composantes stationnelles en milieu aquatique. I-Description d'un plan d'observations complet par projection de variables. Acta OecolOecol Gen 8(3): 403-426.

Dudgeon D. 1984. Longitudinal and temporal changes in functional organization of macroinvertebrate communities in the Lam Tsuen River, Hong Kong. Hydrobiologia 111: 207-217.

El Agbani MA. 1984. Le réseau hydrographique du bassin versant de l'oued Bou Regreg (plateau central marocain). Essai de biotypologie. Ph.D. thesis, Université Claude Bernard, Lyon, France, 147 p.

El Agbani MA, Dakki M, Bournaud M. 1992. Étude typologique du Bou Regreg (Maroc) : les milieux aquatiques et leurs peuplements en macroinvertébrés. Bull Ecol 23(1-2): 103-113.

El Alami M. 1989. Étude hydrobiologique d'un réseau hydrographique Nord-Rifain, l'Oued Laou: typologie, écologie et biogéographie des Ephéméroptères. Ph.D. thesis, Université Mohamed V, Rabat, Morocco, $187 \mathrm{p}$.

El Alami M. 2002. Taxonomie, écologie et biogéographie des Éphéméroptères du Rif (Nord du Maroc). Ph.D. thesis, Tétouan, Morocco, $420 \mathrm{p}$.

Gaertner JC. 1997. Organisation des assemblages démersaux dans le golfe du Lion : structures spatiales et stabilité temporelle. Thèse de doctorat, Université de la Méditerranée, Centre d'Océanologie de Marseille, Marseille, France, 139 p. + annexes.

Gagneur J, Thomas AGB. 1988. Contribution à la connaissance des Ephéméroptères d'Algérie. I. Répartition et écologie (1ère partie) (Insecta, Ephemeroptera). Bull Soc Hist Nat 124: 213.

Graça MAS, Coimbra CN, Santos LM. 1995. Identification level and comparison of biological indicators in biomonitoring programs. Cienc Biol Ecol Syst (Portugal) 15(1/2): 9-20.

Hawkes HA. 1975. River zonation and classification. in: B.A. Whitton, ed. River ecology. London, UK: Blackwell, pp. 312-374.

Hawkins CP, Sedell JR. 1981. Longitudinal and seasonal changes in functional organization of macroinvertebrate communities in four Oregon streams. Ecology 62(2): 387-397.

Heino J, Muotka T, Mykra H, Paavola R, Hamalainen $H$, Koskenniemi E. 2003. Defining macroinvertebrate assemblage types of headwater streams: Implications for bioassessment and conservation. Ecol Appl 13: 842-852.

Illies J, Botosaneanu L. 1963. Problèmes et méthodesde la classification et de la zonation écologique des eaux courantes, considerees surtout du point de vue faunistique. Verh Internat Verein Limnol 12: 1-57.

Leland HV, Fend SV. 1998. Benthic macroinvertebrate distributions in the San Joaquin River, California, in relation to physical and chemical factors. Can J Fish Aquat Sci 55: 1051-1067.
Lytle DA, Poff NL. 2004. Adaptation to natural flow regimes. Trends Ecol Evol 19: 94-100.

Mabrouki Y, Taybi AF, Chavanon G, Vinçon G, Berrahou A. 2016a. Contribution à l'étude des plécoptères dans le Maroc Oriental et le bassin versant de la Moulouya et leur distribution en fonction des étages bioclimatiques. J Mater Environ Sci 7(6): 2178-2193.

Mabrouki Y, Taybi AF, Bensaad H, Berrahou A. 2016b. Variabilité spatio-temporelle de la qualité des eaux courantes de l'Oued $\mathrm{Za}$ (Maroc Oriental). J Mater Environ Sci 7(1): 231-243.

Mabrouki Y, Taybi AF, El Alami M, Berrahou A. 2017a. New and interesting data on distribution and ecology of Mayflies from Eastern Morocco (Ephemeroptera). J Mater Environ Sci 8(8): 2832-2859.

Mabrouki Y, Taybi AF, Berrahou A. 2017b. L'évolution spatiotemporelle de la qualité des eaux courantes de l'Oued Melloulou (Maroc). Rev Sci Eau 30(3): 213-225.

Mabrouki Y, Taybi AF, Berrahou A, Chaabane K, Legssyer B. 2018. Case study of the freshwater shrimp Atyaephyra desmarestii (Millet, 1831) (Crustacea, Decapoda) in the watershed of Moulouya and Eastern Morocco. Vie et Milieu 68(4): 175-183.

Manly BFJ. 1991. Randomization and Monte Carlo methods in biology. London: Chapmall \& Hall, 281 p.

Metcalfe-Smith JL. 1994. Biological water-quality assessment of rivers: Use of macroinvetebrate community. in: P. Calow, G.E. Petts, eds. The rivers handbook (II). Oxford: Blackwell Scientific, pp. 144-170.

Ormerod SJ, Edwards RW. 1987. The ordination and classification of macroinvertebrate assemblages in the catchment of the River Wye in relation to environmental factors. Freshw Biol 17: 533-546.

Oscoz J, Galicia D, Miranda R. 2011. Identification guide of freshwater macroinvertebrates of Spain. Berlin, Germany: Springer Science \& Business Media, $153 \mathrm{p}$.

Paavola R, Muotka T, Virtanen R, Heino J, Kreivi P. 2003. Are biological classifications of headwater streams concordant across multiple taxonomic groups? Freshw Biol 48: 1912-1923.

Platts WS, Megahan WF, Minshall GW. 1983. Methods for evaluating stream, riparian and biotic conditions, Gen. Tech. Rep. INT-138. U.S. Department of Agriculture, Forest Service, Intermountain Forest and Range Experiment Station, Ogden, $70 \mathrm{p}$.

Robinson CT, Minshall GW. 1986. Effect of disturbance frequency on stream benthic assemblages structure in relation to canopy cover and season. $J N$ Am Benthol Soc 5: 237-248.

Singh HR, Nautiyal P. 1990. Altitudinal changes and the impact of municipal sewage on the community structure of macrobenthic insects in the torrential reaches of the river Ganges in the GarhwalHimalaya (India). Acta Hydrobiol 32: 407-421.

Tachet H, Richoux P, Bournaud M, Usseglio-Polatera P. 2010. Invertébrés d'eau douce: systématique, biologie, écologie. Paris : CNRS Éditions, $607 \mathrm{p}$.

Tate CM, Heiny JS. 1995. The ordination of benthic invertebrate communities in the south platte River Basin in relation to environmental factors. Freshw Biol 33: 439-454.

Taybi AF. 2016. Hydrobiological study of the Moulouya: Structure of the biodiversity and longitudinal zonation of benthic invertebrates. Ph.D. thesis, Université Mohamed Premier, Oujda, Morocco, 270 p. (in French).

Taybi AF, Mabrouki Y, Berrahou A, Peris-Felipo FJ, Chaabane K. 2016a. Contribution à l'étude de la relation "plante-hôte-parasite » entre Elodea canadensis Michx., Hydrellia sp. (Diptera) et Ademon decrescens (Nees, 1811) (Hymenoptera, Opiinae) dans le bassin versant de la Moulouya (Maroc). J Mater Environ Sci 7(7): 24452452 . 
Taybi AF, Mabrouki Y, Berrahou A, Chaabane K. 2016b. Évolution spatiotemporelle des paramètres physicochimiques de la Moulouya. J Mater Environ Sci 7(1): 272-284.

Taybi AF, Mabrouki Y, Ghamizi M, Berrahou A. 2017a. The freshwater malacological composition of Moulouya's watershed and Oriental Morocco. J Mater Environ Sci 8(4): 1401-1416.

Taybi AF, Mabrouki Y, Chavanon G, Berrahou A, Millán A. 2017b. New data on aquatic beetles of Morocco (Coleoptera Adephaga: Gyrinidae, Haliplidae and Dytiscidae). Baltic J Coleopterol 17(1): 83-106.

Taybi AF, Mabrouki Y, Berrahou A, Ait El Abed A. 2018a. Bioecology of Potamon algeriense (Herbst, 1785) (Crustacea, Decapoda) in the watershed of Moulouya and Oriental Morocco. Anim Biodiv Conserv 41(2): 267-274.
Taybi AF, Mabrouki Y, Chavanon G, Berrahou A, Millán A. 2018 b. New data on the distribution of aquatic bugs (Hemiptera) from eastern Morocco with notes on their chorology. Zootaxa 4459(1): 139-163.

Ulfstrand S. 1967. Microdistribution of benthic species (Ephemeroptera, Plecoptera, Tricoptera, Diptera Simuliidae) in lapland streams. Oikos Suppl 10: 1-120.

Vaughan IP, Diamond M, Gurnell AM, Hall KA, Jenkins A, Milner NJ, Naylor LA, Sear DA, Woodward G, Ormerod SJ. 2009. Integrating ecology with hydromorphology: A priority for river science and management. Aquat Conserv Mar Freshw Ecosyst 19: $113-125$.

Vinson MR, Hawkins CP. 1996. Effects of sampling area and subsampling procedure on comparisons of taxa richness among streams. J N Am Benthol Soc 15: 392-399.

Cite this article as: Mabrouki Y, Taybi AF, El Alami M, Berrahou A. 2019. Biotypology of stream macroinvertebrates from North African and semi arid catchment: Oued Za (Morocco). Knowl. Manag. Aquat. Ecosyst., 420, 17. 